\title{
Believing in God the Father: Interpreting a phrase from the Apostle's Creed
}

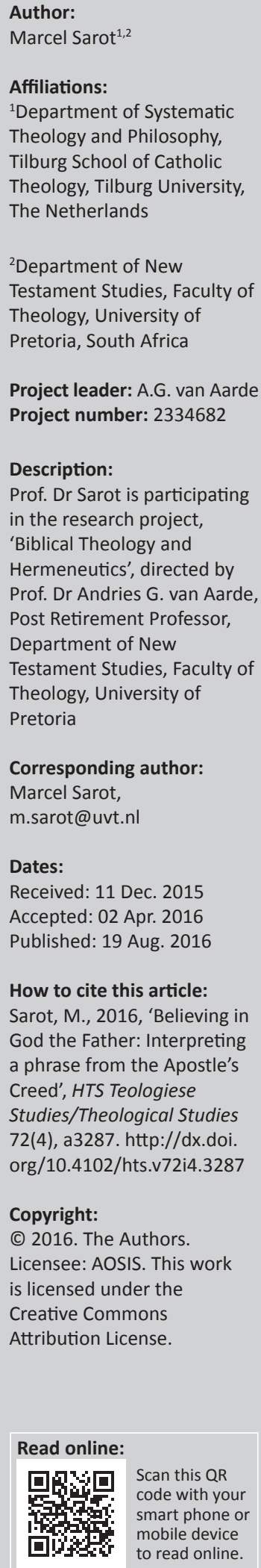

\begin{abstract}
In our days, the creedal phrase 'I believe in God the Father almighty' is interpreted primarily along Trinitarian lines: It is applied to God as the Father of Jesus Christ. Here I argue that it has a dual background: in Jesus' prayer practice, in which He consistently addressed God as 'Father', and in the Hellenistic habit of referring to the Creator as 'Father'. I discuss Jesus' use of the term 'Father' against its Old Testament background, and argue that it primarily points to the intimacy of Jesus' relationship with His father. Against the Hellenistic background, however, the metaphor 'Father' means 'he who brings forth effortlessly'. Finally, I discuss some gender issues connected with the use of the term 'Father' for God.
\end{abstract}

\section{Introduction}

The Apostles' Creed starts with a confession that is for many difficult to sing or say wholeheartedly: 'I believe in God the omnipotent Father, Creator of heaven and earth'.

The expression in this sentence that creates most difficulties for contemporary people is 'omnipotent Father'. It is the maleness evoked by the term 'Father' that creates these difficulties, and they are exacerbated by the adjective 'omnipotent'; together, these two terms are easily interpreted as denoting an 'authoritarian Father'. And that is not what we, as Christians, believe in. Nor is it what early Christians wanted to express by this phrase. Our understanding of it, however, is hindered by the fact that we hear it in our context and not in theirs. Here I intend to retrieve some aspects of the original context, a context that was largely Biblical, and thus to show that and why the omnipotent Father of the Apostles' Creed is misunderstood if we take it to mean 'authoritarian Father'. I will proceed in two steps:

1. I will suggest - following Paul Ricoeur and Janet Martin Soskice - that Jesus' use of the term Abba for God can only be understood against the Old Testament's iconoclastic tendencies that include a repression of the use of the term 'Father' for God;

2. I will suggest that when the Apostles' Creed calls God Father, this should be understood not only against the background of Jesus calling God Abba, but also against the Hellenistic background in which 'Father' can be understood as creator. That background, I will suggest, can also explain the maleness of the metaphor.

I would like to begin by underlining that when we speak of God as Father, we speak metaphorically (Reinhartz 1999: passim). God is not literally a Father, for who is literally father is male, while God is not a sexed Being. As I use the term 'metaphor', to say that a word is used metaphorically is not to say that there is no reality corresponding to it. In Janet Martin Soskice's terms: This metaphor is reality-depicting (Soskice 1985:141 et passim). As Sallie McFague has made clear, using terms metaphorically does mean 'spotting a thread of similarity between two dissimilar objects, events or whatever, one of which is better known than the other, and using the better known one as a way of speaking about the lesser known' (McFague 1982:15). As a result, metaphors 'always contain the whisper, it is and it is not' (McFague 1982:15). 'An ever-present danger, however, is that we shall fail to hear the whisper. We become so used to looking on A as B that we fail to notice the differences between them' (Brümmer 1993:8). This danger is especially acute in what we call dead metaphors, metaphors that are conventionally fixed in our language to such a degree that we no longer experience them as metaphors. Talking about the leg of a table or the foot of a mountain is an obvious example. For many people, I am afraid, talking about God as Father falls into the same category. They believe that God is Father, and no longer experience this use of the term 'Father' as metaphorical. They no longer hear the whisper it is not. In the history of theology, the Arians took God to be literally a Father (Soskice 2007:69). In our time, the Mormons may be mentioned (Robinson 1992). 
For people who tend to take the designation of God as Father as literal or almost literal, it is healthy to be reminded of the fact that while Jesus consistently addressed God as Father, this was in His time far from common, and one might even argue that it was revolutionary. In the New Testament, Jesus calls God Father more than 170 times, and in prayer He never addresses God otherwise. When we compare this with the way in which God was addressed in the Hebrew Scriptures, we find that in this much larger body of literature God is called Father a mere fifteen times, and - with one exception - never in prayer $^{1}$. In the Hebrew Scriptures, God is not 'our Father', but 'the God of our Fathers', and that is quite something else. In neighbouring religions, gods can be called fathers without hesitance; they can even be biological fathers of human beings. In this respect, the Mosaic religion is much more reserved. The relationship between God and humans is seen in terms of covenant rather than kinship; God is Creator, Liberator and Lawgiver rather than Father. When it comes to making images of God, the Hebrew Scriptures are strikingly iconoclastic. The portrayal of God in images, especially sculptured images, is associated with idolatry and absolutely forbidden (Ex 20:3-6, Lv 26:1, Nm 33:52, Dt 4:16-19, 27:15). When God's Name is revealed from the burning bush in Exodus 3, the Name that is given refers without having any obvious meaning and, moreover, it is not supposed to be pronounced. Using the tetragrammaton YHWH for God seems anti-anthropomorphistic in itself. All precautions are taken to avoid that we can capture God in a name. Given this context, it seems hardly to be a coincidence that the designation of God as Father appears so seldom in the Hebrew Scriptures; this seems to be a case of deliberate avoidance of an offensive way of speaking. Moreover, of the few cases in which the term 'Father' is used, some explicitly underline this reserve. Take Jeremiah 3:19b-20 (NRSV), for example:

I thought you would call me, My Father,

and would not turn from following me.

Instead, as a faithless wife leaves her husband,

so have you been faithless to me, O house of Israel,

says the Lord.

Two things are worth noticing in this quotation. Firstly, the image of a father ('I thought you would call me, My Father, and would not turn from following me') is immediately followed by that of a husband ('as a faithless wife leaves her husband, so have you been faithless to me'). Both images are used for God in relation to Israel, and both are incompatible: one cannot simultaneously be a father and a husband to the same woman. This alternation of incompatible images underlines that neither of both can be taken literally². Secondly, the situation in which Israel addresses God as Father is not the present situation, but one of eschatological salvation (See also Jr 31:9, Ps 89:26).

1.Soskice (2007:75) claims that God is called Father in the Hebrew Scriptures only 11 times, and never in prayer, without giving references to the Biblical texts; Stein (1996) gives the figure of 15 times and provides a list of references: 'God is Stein (19) gives the figure of 15 times and provides a list of references: 'God is specifically called the Father of the nation of Israel (Dt 32:6; Is 63:16; [twice] 64:8, Jr 3:4 Jr 3:19; 31:9; Ml 1:6; 2:10) or the Father of certain individuals ( $2 \mathrm{Sm} \mathrm{7:14;1} \mathrm{Ch}$ $17: 13 ; 22: 10 ; 28: 6$; Ps $68: 5 ; 89: 26)$ only fifteen times'. The exception where God is ' 'Father' in prayer is Isaiah 63-64.

2.We see a similar alternation of metaphors in Deuteronomy, when God is called Father in Deuteronomy 32:6 and Mother in 32:18.
When Jesus subsequently addresses God as Father, we may take this as a sign that in Him, the eschatological salvation announced by the prophets is indeed breaking through. Moreover, Jesus qualifies the image by using a specific term, $a b b a$, which the first Christians judged to be so important that they handed over the Aramaic term in three instances in the New Testament (Mk 14:36; Rm 8:15-16; Gl 4:6). This is a term that presupposes a certain degree of intimacy - scholars disagree about the exact degree - and that thus readjusts the image again. Thus, in Mosaic religion God was not a father, the prophets were looking forward to the time in which God would be both Father and Husband, and Jesus' relationship with God was intimate like that with the father of the family.

We need to regain this background to acquire a feeling for how daring, yes how revolutionary, Jesus' way of addressing God as Father was. Both the Hebrew Scriptures and the intertestamental literature (Stein 1996) avoided addressing God in this way, even though it was common in neighbouring religions. I do not want here to enter into the discussion about who was first in introducing this new way of addressing God: Jesus or other first-century rabbis ${ }^{3}$. It seems likely, however, that it was Jesus who brought about this change because the term $a b b a$ is so strongly attested that it is likely to have been novel at the time. Moreover, when other early rabbinical texts are mentioned as referring to God as 'Father', we must be aware of the fact that the dating of this type of texts is often quite uncertain (York 1974:49-62). But it does not really matter: Even if Jesus was in this respect indebted to other contemporary rabbis, all of them could thus address God as Father only against a background that had been so reluctant to do this and generally so anti-anthropomorphistic that they did not run the risk that the image would be taken literally and thus become idolatrous. When Jesus addresses God as Father, He does not look backward to a past in which God generated humanity in the way fathers generate children, but forward to a nearby future in which humanity will find its fulfilment in a new intimacy with the Father, an intimacy opened up to us by the Son and achievable only by becoming one with Him. Once again, Jesus' way of addressing God as Father did not become possible against a background in which the Fathership of God was common ground. It was the other way round: The way in which Jesus addressed God as Father was daringly novel, and Jesus could introduce it only against a background in which it was uncommon. Moreover, He could only do this because of the special relationship $\mathrm{He}$ Himself had with the Father; there is no Father without Son (and no Son without Father, of course). It is the Son who makes the Father known to us (Jn 1:18). And it is only because the Son was the firstborn among many brothers and sisters (Rm 8:29) that we may call God Father.

True as this may be, with the first article of the Apostles' Creed we enter another atmosphere. I quote it once again:

I believe in God the omnipotent Father, Creator of heaven and earth.

3.This is the position of Goshen-Gottstein 2001 . 
Even though the phrase 'I believe in' can plausibly be read as 'I trust in', the designations 'the omnipotent Father, Creator of Heaven and Earth' do not suggest the intimacy of the family. The second part of the phrase, 'Creator of heaven and earth', suggests that God has brought forth everything there is, and therefore everything is dependent on God. In this connection, it is important that the term 'creating' should not be interpreted as 'being the first Cause in a chain of causes', for that would give rise to the question 'who has created this first Cause?' God creates, rather, by bringing forth the entire chain of causes and effects. He acts on a level that is different from that of the world in which we live; nevertheless, this world is the result of God's creative agency.

In this connection, what does the 'omnipotent Father' mean? In his classic monograph Early Christian Creeds, J.N.D. Kelly has shown that the most common meaning of the term 'Father' in its application to God in the Hellenistic environment was that God was Creator. In this connection, he refers to Epictetus and Philo of Alexandria. According to Kelly, also '(t)o Christians of the second century this was beyond any question the primary, if by no means the only, significance of the Fatherhood of God' (Kelly 1999:136). He mentions a number of examples. St Clement of Rome spoke of 'the Father and Creator of the whole universe' (1 Clem. 19:2) and of 'the demiurge and Father of the ages' (1 Clem. 35:3). Justin Martyr spoke of God as 'the Father of the universe' (1st Apology 63, 65), as 'the Father of all, who is unbegotten' (2nd Apology 6) and as 'The Creator, the God and Father of all things' (Dialogue with Trypho 7). Irenaeus mentions that God the creator is called Father in respect of His love (Against Heresies V 17,1). Theophylus of Antioch gives as reason for calling God Father that He 'is before all things' (To Autolycus I 4). Tatian calls God 'the Father of both sensible and invisible things' (Address to the Greeks 4). Again, when Novatian talks about God the Father, it is clear that he talks about the Creator:

The Rule of truth requires that we should first of all things believe in God the Father and Lord Omnipotent; that is, the absolutely perfect Founder of all things, who has suspended the heavens in lofty sublimity, has established the earth with its lower mass, has diffused the seas with their fluent moisture, and has distributed all these things, both adorned and supplied with their appropriate and fitting instruments. (Novatian, On the Trinity 1)

Of course, more examples could be given, but I assume that these examples are sufficient to illustrate the point I wanted to make: If we read the Apostles' Creed against the background of the Hellenistic culture from which it originated, the interpretation of Father as Creator becomes a natural interpretation. One of the reasons why this interpretation could so easily be adopted in the early Church is that also in some of the few texts from the Hebrew Scriptures in which God was named as Father to indicate a present reality, this Fathership in fact meant Creatorship. We see this, for example, in Deuteronomy 32:6 ('Is this the way you repay the LORD, O foolish and unwise people?
Is he not your Father, your Creator, who made you and formed you?') and Malachi 2:10 ('Have we not all one Father? Did not one God create us?').

Once we have seen that in the Apostles' Creed 'Father' can be read as 'Creator', the adjective 'omnipotent' falls into its place as well: the Creator of all should be omnipotent. Augustine makes this connection quite clear:

His omnipotence ... was necessary for all creation in order that it might be created. He is omnipotent to make things great and small; $\mathrm{He}$ is omnipotent to make things heavenly and earthly; He is omnipotent to make things immortal and mortal; $\mathrm{He}$ is omnipotent to make things spiritual and corporeal; He is omnipotent to make things visible and invisible; He is great amid great things and He is not small amid the smallest. In a word, He is omnipotent to make all things which He may have desired to make. (Augustine, Sermon 213)

That the Apostles' Creed indeed means the Creator of Heaven and Earth when it confesses the omnipotent Father can also be seen from the fact that in the early versions of the Apostles' Creed the phrase 'Creator of heaven and earth' is absent (MacLear 1893:69); it was added only after the Hellenistic era when it was no longer self-evident that by the 'omnipotent Father' the Creator of heaven and earth was mentioned.

This brings me, then, to the final step in my argument. We have seen already that against the background of the Old Testament, there was little risk that Jesus' way of addressing God was taken literally. It underlined the intimate nature of His relationship with God, nothing more and nothing less. I have not speculated about the question 'why He used the image of the male parent?'. We have also seen that in the Apostles' Creed, while Jesus' way of addressing God obviously resonates, another meaning of 'Father' resonates as well: the Father is the Creator of heaven and earth. From that context, the adjective 'omnipotent' gets its meaning: It is the craftful Creator that is intended, not some authoritarian Father. Against this background, it also becomes clear why the Hellenistic culture uses the male parent as image: The efforts involved in childbirth are the mother's, not the father's, and, therefore, if one wants to emphasise that the omnipotent Creator brought forth His creation without effort, it is the male metaphor one needs, not the female one.

Thus, while Jesus' use of the term 'Father' may be taken to be relatively gender-neutral, the Hellenistic use of the term 'Father' for the Creator needs the maleness of the metaphor and both backgrounds jointly resonate in the Apostles' Creed. In later interpretations, the fact that 'Father' in the Apostles' Creed also means 'Creator' was almost entirely forgotten. Simultaneously, however, the deliberate avoidance of the term 'Father' in the Old Testament receded into the background, and the whisper 'It is not' lost its vigour. In times when gender issues were not attended to in our culture in general, the term 'Father' could easily be misunderstood as implying a male God. My suggestion is that in our time the whisper 'It is not' may no longer be overlooked, and we should again become conscious of the fact that it is not a matter of course 
that we may call God 'Father', but that when we do this we use a daring image - though we do believe that it is an image to which reality corresponds. In the Roman Catholic liturgy, this awareness is kept alive by the audemus dicere of the introduction to the Lord's Prayer: Only on the instigation of Jesus we dare say 'Our Father'. By taking the audemus dicere seriously, we may keep the awareness alive that God's Fathership is no ordinary fathership, and thus we reduce gendered overtones, even while we are aware that 'Father' refers not only to Jesus' $a b b a$ but also to the Creator of heaven and earth.

Finally, I should end with a disclaimer. In the above, I am concerned with the interpretation of the term 'Father' in the Apostles' Creed. Though my interpretation is informed by other texts and it is relevant to the interpretation of the term 'Father' as applied to God in other contexts, I do not intend to make claims about the interpretation of the term 'Father' in these other contexts.

\section{Acknowledgements Competing interests}

The author declares that he has no financial or personal relationships which may have inappropriately influenced him in writing this article.

\section{References}

Augustine, Sermon 213, transl. Sister Mary Sarah Muldowney, R.S.M., viewed from https:// archive.org/stream/fathersofthechur009512 mbp/fathersofthechur009512mbp_ djvu.txt

Brümmer, V., 1993, The model of love, Cambridge University Press, Cambridge.

Goshen-Gottstein, A., 2001, 'God the Father in rabbinic Judaism and Christianity: Transformed background or common ground?', Journal of Ecumenical Studies 38, 470-504.

Irenaeus of Lyon, ca. 175-185 CE, Against heresies.

Justin Martyr, ca. 155-161, Dialogue with Trypho.

Kelly, J.N.D., 1999, Early Christian Creeds, 9th impression of the 3rd edn., Longman, rpt PoD New York.

MacLear, G.F., 1893. An introduction to the Creeds, Macmillan, New York, NY.

McFague, S., 1982, Metaphorical theology: Models of God in religious language, Fortress Press, Philadelphia, PA.

Novatian, On the Trinity, viewed from http://www.newadvent.org/fathers/0511.htm [accessed on 25 November 2016].

Reinhartz, A., 1999, God the Father in the Gospel of John, Semeia 85.

Robinson, S.E., 1992, 'God the Father: Overview,' in, D.H. Ludlow (ed.), Encyclopedia of Mormonism, pp.548-550, Macmillan, New York, NY.

Soskice, J.M., 1985, Metaphor and religious language, Clarendon Press, Oxford.

Soskice, J.M., 2007, The kindness of God: Metaphor, gender, and religious language, Oxford UP, Oxford.

Stein, R.H., 1996, 'Fatherhood of God', in W.A. Elwell (ed.), Baker's evangelical dictionary of Biblical Theology, Baker Book House, Grand Rapids, MI.

Tatian, Address to the Greeks 4, transl. J.E. Ryland, viewed 26 November 2016, from http://www.earlychristianwritings.com/text/tatian-address.html

Theophylus of Antioch (ca. 180-185 CE), To Autolycus.

York, A.D., 1974, 'The dating of targumic literature', Journal for the study of Judaism 5, 49-62. http://dx.doi.org/10.1163/157006374X00043 